\title{
Exploration of College English Teaching Based on Linguistic Theory
}

\author{
Na Li \\ Xi'an International University, Xi'an Shaanxi, China, 710077
}

Keywords: linguistics, College Teaching Method, English learning

Abstract: in English teaching, linguistics is a foundation. The basic curriculum is concerned with the nature and regulation of language which plays an important role. Learning linguistics can help students better understand and understand English by the way of using the vocabulary and writing articles exactly. Therefore, it is necessary to teach English in colleges and universities by the thoery of linguistics. Based on the theory of learning, how to improve the quality of teaching is capable ofeffective exploration. English is a comprehensive language whose learning tasks integrated with strong combination and practicability are deficient. It also caused some difficulties which is lack of English environment for college students' English learning. In order to effectively mention the application of English to college students, teacher should give full play to linguistic knowledge. In the perspective of English teaching from the views of language itself and theory ,Learning problems should solve the current English Teaching in Colleges and Universities

\section{Linguistics is a subject that is a scientific language for studying human language}

Attention to us, Language learning, which is based on human language and language learning, and language learning should be clearly separated from each other, only for language learning. So linguistics which includes several fields of speech such as speech structure (grammar), morphology, syntax, and speech is a branch of human culture. The application scope of linguistics and the historical development of language. And other language related aspects, the development of linguistics is earlier than that of linguistics. At first, from the interpretation of ancient documents, the main purposes are mainly established for studying philosophy, history and literature. In the Han Dynasty, Chinese linguistics was founded. following as the words, phonology and exegesis, India and Greece are also in early century. Grammar was established from third Century to fourth Century. The establishment of Dai linguistics started in the early eighteenth Century. Since the western linguists have discovered Indo European languages, the similarities between Sanskrit has began to emerge. The purpose is to study the primitive language. It was not until twentieth Century that linguistics began to enter the development of language and its application began to separate research gradually, and began to promote step by step. The differentiation between applied linguistics and theoretical linguistics. 


\section{Current situation of College English Teaching in China}

The development of College English teaching has been very long development of history, it also accumulates in teaching methods and methods. With some experience, there are still some problems which leads to the current English teaching process and cause a series of problems including the writings, reading comprehention ect.

\subsection{Students lack enthusiasm for English learning}

Compared with the learning state of the University, the learning of the university is relative. It is said that there is much less compulsion in study and life which are more freedom .So in the aspect of learning, supervision, which is without teachers, depends entirely on students' knowledge of thirsty attitude and interest. But at present, many students are not interested in learning English, while students are required to accumulate in the teaching of College English. Active participation leads to teaching objectives which can not be achieved in the classroom. And college students who have been very strong in age and psychology.

Autonomy is not in accordance with management, plus college English teaching takes a lot of practice and reading. Therefore, under the pressure of university learning English, students deeply lost interest in learning English.

\subsection{Vague learning motivation}

College English is divided into liberal arts as the result of the students who major in science and engineering are more inclined to learn English. But in English learning, the understanding of English is mainly about grammar which is in daily application communication and reading writing. It is not commonly used, so for science and engineering students who learning English is only a matter of understanding. It is insufficient on the surface, which will lead to science and engineering. Students are lack of accurate orientation in learning English motivation.

\subsection{Weak on the direction of discipline}

In traditional English teaching, English learning is regarded as a tool for learning and communication not as a subject. During the university period, the students whose major is no matter liberal arts or Science have to learn English. Theoretically, there is a kind of science mandatory indicators, especially for students of science and Engineering, English learning is basically useless. So learning English has become a kind of unactive and solid knowledge. In order to cope with examinations, this situation will only be more hindrance. It hinders students' interest in learning English.

\section{Practice of English teaching and learning under the guidance of linguistic theory}

College English learning is mainly divided into listening, speaking and reading. The five aspects of writing and translation are going throughout English teaching. We can use the linguistic theory as the way to teach college English. Learning to guide and draw lessons from aspects of Linguistics comes very extensively in the origin of language history, language society, structure, language mastery, psycholinguistics and some related subjects. In the teaching of College English, we can use the language theory to refer to college English as a approach to guide teaching. 


\subsection{Creation of a good English learning environment}

When Linguists are doing research, they find that the children put emphasis on second language in learning first language and adult learningthis by aspect of language acquisition. The difference between them is that language learning environment is very extremely important. For example, English for Chinese students studying in the United States whose level is far more than that of domestic students. The level is much higher which means the learning circle of language. Environment has a great influence on English learning. currently, the application of English in English teaching is not yet forming the sense of students who feel that there is nothing to learn English. The view of extension will be made to a certain extent and deep for students' initiative in learning English. Therefore, teachers can do everything in the process of English teaching. It is possible to create a relaxed and enjoyable learning for students. Atmosphere of and providing more English application for students in the communicative environment which enables students to learn in class. English knowledge can be applied to life and study. Stimulating students' interest in learning English can also help them who learn in class in the process of communication. The transformation of English theory into practical application and improvement of students. The ability to use language to consolidate learning is in the classroom for knowledge. In order to ensure students' success in communication. Teachers can teach students some corresponding questions which is related to Knowledge and skills. Smooth English communication can be promoted. The self-confidence of students enhances the English language. The desire for knowledge, and the deeper understanding of the charm of English with the purpose of enhancing students' interest and enthusiasm in Initiative of learning English.

\subsection{The design of classroom content and teaching content}

Many students hate English curriculum because of English content itself. In the teaching of English, most of them are backed up the words, reading, translation and listening are the main factors. In the course of teaching, it will be boring and boring. Teachers should appropriately teach courses in the process of teaching whose content is designed to avoid boring. The preaching of taste is based on students' attitude towards English learning for different guidance to students of various majors.

There are many different paths of thinking about things, so English is distinguish from points of interest in the course. Aim to dig deeper into the interests of students and expand them and cultivate students' interest by increasing classroom efficiency. And teachers who can introduce students to different majors are facing various students at the same time. With the same content, introduce students' major into English teaching. The content can focus on students' attention and reinforcement their thirst for knowledge in English.

\subsection{Pay attention to the gap between students}

Although our students have been in contact with English since primary school. The degree of mastery of English knowledge is also very different. Students have strong oral English but weak grammar, some students have strong ability to read, but dictation is weak. Teachers should pay attention to the existence of these differences. The difference between students and learning styles should be clear. Try the best to understand and respect them, so this requires teachers to be respected. Students can do a test before teacher gives English lesson. The teachers will know each student's English learning level. In the hall, students' learning methods were carried out in a timely manner to understand the individual differences of each student. It is the main factor that understanding the individual differences of each studentand guiding students to develop good 
learning habits and attitude which masters correct learning methods and help students understand their learning characteristics and learners according to students' mastery of English.

\subsection{According to students' mastery of English, teach students in accordance with their aptitude}

For students with poor oral English, So that they can start practicing from the simplest listening and speaking with practice constantly and formation a language habit. Vocabulary can be accumulated in the process of language practice.

To promote the continuous progress of Chinese language. Students in the classroom can feel the progress and teacher's affirmation. To a certain extent, it will increase the enthusiasm for learning English. Even when pride is satisfied, English is spoken. Learning generates great interest. Teachers can also learn. Instilling the meaning of English learning to increase students' right

A deeper understanding of English learning and changing students' English turns examinations into autonomous learning by Practice.

\subsection{Change the traditional teaching methods and establish the teaching mode of the center students oriented}

Under the traditional teaching mode, teachers are using the way of teaching, indoctrination which is often used in the classroom. It is difficult for students to learn in this way of learning actively. To improve students' initiative in learning can completely change the traditional teaching methods and discard them. The teacher centered teaching mode is based on students. The center's English teaching class. Teachers try to enrich teaching activities and prepare various courses. The task is to enrich learning activities and improve learning. It is am important way to develop an initiative is to enable students. Learning from English is passive. Giving full play to students' learning ability can improve classroom effectiveness to achieve maximum teaching objectives.

\section{Conclusion}

English is one of the international languages. In terms of learning, working and communicating without borders, the importance of learning English is self-evident. College English teaching pays more attention to the specific English language application. This is for students' learning and future development. It has profound significance, so the teaching of College English is of great significance. The study of methods and practice is the current university education occupying the top priority. College English teaching is not only a discipline, but also a discipline. Teachers are not only learning methods, but teaching. In the process of applying linguistic theories to English, teaching methods enrich and change the past for examination. And learning the state of English, actively cultivating students' right interest in English courses enhances students' initiative and enhance classroom efficiency. Focus on training students' ability to learn the practical application of English and to strengthen the language is the ability to learn English as the important goals. While according to the introduction of different categories of linguistics. It is good for students to understand English learning correctly. The learning motivation is adjusted to learning attitude and passive learning for actively adding language to classroom teaching. The exchange of College English teaching is not just a study, but merely a means of learning. In the process of teaching, we apply linguistic theories to English. The approach of teaching is enriched and changed. The state of learning English in examinations actively cultivates students' interest in English courses and students' enthusiasm and initiative and enhance classroom efficiency. The important goal of language in the points of paying attention to training students' ability to learn English and the 
practice of developing English and using ability to enhance language application ability. At the same time, according to linguistic differences, the introduction of category enhances students' learning of English. We must understand and set up correct learning motivation and correcting learning state in passive learning is active during classroom teaching. Appropriately, joining language exchange enriches classroom teaching circles, better for improving classroom efficiency.

\section{References}

[1] Chen Xiao, corpus linguistics and its application [J] Journal of Foshan University, 2016 (4)

[2] Du Shi Chun. Prospect and funding of corpus linguistics Source sharing [J]. modern foreign languages, 2015 (4)

[3] Hu Zhuang Lin. Linguistics course [M] Beijing: Peking University Publishing house, 2007

[4] Li Ya Ya. Corpus linguistics in foreign language teaching Applied [J]. Shaanxi education, 2013 (5)

[5] Liu Guobing. Ontological thinking of corpus linguistics Interpretation of [J]. Journal of Henan Normal University, 2014(2)

[6] army, Zhang Le. New developments in Corpus Linguistics A summary of the seminar on corpus linguistics development strategy[J]. contemporary foreign language studies, 2010 (2)

[7] Xiao Zhonghua, Xu Jia Jin. Corpus and language education [J]Foreign language education in China, 2008 (2)

[8] Yang Huizhong. Corpus Linguistics: applied research and contribution

[9] Li Cun, applied linguistics motivation theory to English class The guiding role of Cheng's teaching in Zhengzhou aviation industry management Journal of science and Social Sciences Edition, 2015 (2)

[10] Hui Wang. Application of Computer teaching Production Technology in College Music Teaching [J]. Journal of Qinghai Normal University (Philosophy and Social Science Edition), 2015, 37(05): 132-136.

Xi'an International University, Xi'an Shaanxi, 710077, Research Direction: Linguistics 